\title{
Enzymatic degradation of granular potato starch by Microbacterium aurum strain B8.A
}

\author{
Fean D. Sarian • Rachel M. van der Kaaij • \\ Slavko Kralj • Dirk-Jan Wijbenga • Doede J. Binnema • \\ Marc J. E. C. van der Maarel • Lubbert Dijkhuizen
}

Received: 15 April 2011 /Revised: 7 June 2011 / Accepted: 7 June 2011 /Published online: 6 July 2011

(C) The Author(s) 2011. This article is published with open access at Springerlink.com

\begin{abstract}
Microbacterium aurum strain B8.A was isolated from the sludge of a potato starch-processing factory on the basis of its ability to use granular starch as carbon- and energy source. Extracellular enzymes hydrolyzing granular starch were detected in the growth medium of $M$. aurum B8.A, while the type strain M. aurum DSMZ 8600 produced very little amylase activity, and hence was unable
\end{abstract}

Dedicated to the memory of Dirk-Jan Wijbenga who passed away in 2002 .

F. D. Sarian · S. Kralj · M. J. E. C. van der Maarel $(\bowtie) \cdot$ L. Dijkhuizen

Microbial Physiology, Groningen Biomolecular Sciences and

Biotechnology Institute (GBB), University of Groningen,

Nijenborgh 7 ,

9747 AG Groningen, The Netherlands

e-mail: m.j.e.c.van.der.maarel@rug.nl

R. M. van der Kaaij · D.-J. Wijbenga • D. J. Binnema

TNO Quality of Life,

Utrechtseweg 48,

3704 HE Zeist, The Netherlands

Present Address:

R. M. van der Kaaij

Microbial Physiology, Groningen Biomolecular Sciences and

Biotechnology Institute (GBB), University of Groningen,

Nijenborgh 7,

9747 AG Groningen, The Netherlands

Present Address:

F. D. Sarian

Institute Technology Bandung,

Jl Ganesha 10,

Bandung 40132, Indonesia

Present Address:

S. Kralj

Genencor International B.V.,

Archimedesweg 30,

2333 CN Leiden, The Netherlands to degrade granular starch. The strain B8.A extracellular enzyme fraction degraded wheat, tapioca and potato starch at $37^{\circ} \mathrm{C}$, well below the gelatinization temperature of these starches. Starch granules of potato were hydrolyzed more slowly than of wheat and tapioca, probably due to structural differences and/or surface area effects. Partial hydrolysis of starch granules by extracellular enzymes of strain B8.A resulted in large holes of irregular sizes in case of wheat and tapioca and many smaller pores of relatively homogeneous size in case of potato. The strain B8.A extracellular amylolytic system produced mainly maltotriose and maltose from both granular and soluble starch substrates; also, larger maltooligosaccharides were formed after growth of strain B8.A in rich medium. Zymogram analysis confirmed that a different set of amylolytic enzymes was present depending on the growth conditions of M. aurum B8.A. Some of these enzymes could be partly purified by binding to starch granules.

Keywords Microbacterium aurum - Alpha-amylase . Scanning electron microscopy · Granular starch · Potato starch

\section{Introduction}

Starch is the major carbohydrate reserve in plants. It consists of amylopectin, a large $\alpha-(1,4)$ linked anhydroglucose polymer with $\alpha-1,6$ linked side chains, and amylose, a linear $\alpha-(1,4)$ linked anhydroglucose polymer. Regular starch contains on average $20-25 \%$ amylose and $75-80 \%$ amylopectin (van der Maarel et al. 2002). In nature, starch in plants occurs in the form of inert granules that differ in size and structure between species (Singh et al. 2003).

Starch is one of the major caloric sources in the human diet. It is also used in many non-food applications, e.g. in 
paper making, adhesives, and oil-drilling fluids. The last few years have seen a considerable interest in starch as a raw material for the production of bioethanol as an automotive fuel supplement. For most of these applications, starch needs to be solubilized, degraded or modified to change its properties, which can be performed either physically, chemically or enzymatically. A well-established industrial conversion process is the hydrolysis of starch into maltodextrins, maltose, and glucose syrups; a process which is performed with acids or specific enzymes. Acid hydrolysis of starch had widespread use in the past but is now largely replaced by enzymatic processing (de Miguel Bouzas et al. 2006; Guzmán-Maldonado and Parades-Lópes 1995; van der Maarel et al. 2002). The industrial enzymatic conversion of starch consists of a heating step to disrupt the granular structure (gelatinization), liquefaction using a thermostable $\alpha$-amylase and subsequent saccharification by glucoamylase and pullulanase enzymes. To reduce processing cost and save energy, enzyme preparations have been developed that hydrolyze granular starch below the gelatinization temperature (Fogarty and Kelly 1990; Robertson et al. 2005). A key property of $\alpha$-amylases acting on starch granules is the presence of one or more Starch-Binding Domains (SBD). Such auxiliary domains bring the biocatalyst into close and prolonged vicinity with starch granules, allowing hydrolysis of the insoluble substrate (Guillén et al. 2009; Rodriguez-Sanoja et al. 2005; Southall et al. 1999). Carbohydrate-binding domains have been classified into 64 different families, based on amino acid similarity and fold (see http://www.cazy.org/CarbohydrateBinding-Modules.html for more information). Nine of these families contain different types of SBDs. CBM20 is one of the best described types; it is related to CBM21, 48 and 53, and occurs in a range of different enzymes with activity on starch including cyclodextrin glucanotransferase, beta-amylase and phosphorylating enzymes (Christiansen et al. 2009). Another clan is formed by CBM25 and 26, which often occur in tandem repeats (Machovic and Janecek 2006).

Amylases are widespread in nature and are produced by all kinds of organisms ranging from microorganisms, plants, insects, to mammals (Bertoldo and Antranikian 2002; Finnie and Svensson 2009; Whitcomb and Lowe 2007). The main function of these amylases is the degradation of starch and glycogen to support the organisms' growth. Most amylases belong to the glycoside hydrolase family 13 (see http://www. cazy.org/GH13.html for a detailed overview) or glycoside hydrolase family 57 (http://www.cazy.org/GH57.html) (Cantarel et al. 2009). Amylases and related enzymes are retaining enzymes using a double displacement mechanism with the formation of a covalent enzyme-substrate intermediate (Uitdehaag et al. 1999).

Various microorganisms have been found to produce granular starch-degrading amylolytic enzymes; many of them are fungal species. Ueda et al. (1974) reported that the fungi Aspergillus awamori and Aspergillus oryzae (Miah and Ueda 1977) produce glucoamylases that adsorb to the granules while degrading them. There are also several reports of granular starch-degrading enzymes from bacteria. For example, Hayashida et al. (1988) reported that an $\alpha$ amylase produced by Bacillus subtilis strain 65 is able to degrade potato and corn starch granules. A similar ability to degrade granular starch was found in Bacillus circulans, Bacillus amyloliquefaciens and Bacillus cereus (Taniguchi et al. 1982; Sarikaya et al. 2000). Within the Actinomycetes, Streptomyces sp. no. 4 produces $\alpha$-amylases which hydrolyzes cassava starch granules (Primarini and Ohta 2000) and Streptomyces limosus produces an $\alpha$ amylase that hydrolyzes corn starch granules with the release of maltose (Fairbairn et al. 1986).

Starch granules are relatively rigid structures and several factors, such as the crystalline structure, presence of cracks and pores, and the granule sizes contribute to the relative resistance of granules to enzymatic degradation (Heitmann et al. 1997; Kong et al. 2003; Tester et al. 2004). Large starch granules have a relatively smaller surface area than smaller granules thus, reducing the chance for enzymes to become absorbed. Therefore large granules are generally less easily degraded than smaller granules (Noda et al. 2005; MacGregor and Balance 1980; Al-Rabadi et al. 2009).

Most of the known granular starch-degrading enzymes show a reasonable hydrolyzing activity on corn, maize and cassava starch granules, but only few enzymes are able to degrade potato starch granules. Enzymes that are capable of degrading potato starch granules are attractive for increasing the range of starch sources suitable for enzymatic hydrolysis. Their detailed characterization may reveal specific protein structural features important for starch granule degradation.

We have isolated a bacterial species from the sludge of a potato starch-processing factory, which was identified as Microbacterium aurum strain B8.A. It was shown to be capable of degrading potato starch granules, in contrast to the type strain M. aurum DSMZ 8600 which showed only minor amylase activity. In this paper, we report characteristics of starch degradation by M. aurum B8.A. It was found to employ an amylolytic enzyme system that initiates granular potato starch degradation by making numerous small pores in the starch granules.

\section{Materials and methods}

\section{Materials}

Potato, wheat and tapioca starches were a kind gift of TNOQuality of Life, (Zeist, The Netherlands). Soluble potato starch Paselli SA2 was obtained from AVEBE (Foxhol, The 
Netherlands). Oligosaccharides, amylose and amylopectin were purchased from Sigma Chemie GmbH (Germany).

\section{Strain isolation and characterization}

Sludge from a wastewater treatment unit of AVEBE, a potato starch-processing factory in The Netherlands, was resuspended in demineralized water, stirred for $3 \mathrm{~h}$, and filtered over glass wool. The filtrate was inoculated into medium containing $20 \mathrm{mM} \mathrm{KH}{ }_{2} \mathrm{PO}_{4}, 11 \mathrm{mM} \mathrm{K}_{2} \mathrm{HPO}_{4}, 0.8 \mathrm{mM} \mathrm{MgSO}_{4} 7 \mathrm{H}_{2} \mathrm{O}$, $6.7 \mathrm{mM} \mathrm{KCl}, 0.07 \mathrm{mM} \mathrm{FeCl}_{3} 6 \mathrm{H}_{2} \mathrm{O}, 23.5 \mathrm{mM} \mathrm{NaNO}$, $\mathrm{pH} 7.2$, and $1 \%(w / v)$ native potato starch granules (sterilized by gamma irradiation). Cultures were incubated at $37{ }^{\circ} \mathrm{C}$ while shaken. Cultures containing granular starch-degrading microorganisms, as judged by the degradation of starch granules observed with light microscopy, were plated on medium containing $18 \mathrm{mM} \mathrm{KH} \mathrm{PO}_{4}, 40 \mathrm{mM} \mathrm{K} \mathrm{HPO}_{4}$, $0.8 \mathrm{mM} \mathrm{MgSO}_{4} 7 \mathrm{H}_{2} \mathrm{O}, 6.7 \mathrm{mM} \mathrm{KCl}, 0.07 \mathrm{mM} \mathrm{FeCl}_{3} 6 \mathrm{H}_{2} \mathrm{O}$, $23.5 \mathrm{mM} \mathrm{NaNO}_{3}$ and $2 \%(w / v)$ agar, $\mathrm{pH}$ 7.2. A top layer was added containing $0.9 \%(w / v)$ agar and $2 \%(w / v)$ native potato starch granules in suspension, added after cooling the agar to $55^{\circ} \mathrm{C}$. Colonies forming a clearing zone in the opaque top layer were selected, and pure cultures were isolated by repeatedly inoculating single colonies on nutrient agar. Morphological, physiological and biochemical studies on the bacterium were carried out according to Bergey's Manual of Determinative Bacteriology (Holt et al. 1994).

Genomic DNA of the isolated granular starch-degrading strain was extracted using the Gen Elute Bacterial Genomic DNA Kit (Sigma-Aldrich, US). 16S ribosomal DNA (rDNA) was amplified using the primers B3F (5'-GGT TAC GTT GTT ACG ACT T-3') and 1492 R (5'-AGA GTT TGA TCA TGG CTC AG-3') (Eurogentec, The Netherlands). The amplification products were purified with Gen Elute PCR Cleaning Kit (Sigma).

Cloning of the PCR product was done by standard methods (Maniatis et al. 1982). The amplified product was ligated into vector XL-TOPO (Invitrogen, The Netherlands) and the recombinant plasmid was sequenced by using $\mathrm{T} 7$ and M13RP primers at GATC Biotech (Germany). Similarity searches with $M$. aurum B8.A DNA sequences were performed with nucleotide collection (nr/nt) sequences at the NCBI website (http://www.ncbi.nlm.nih.gov) using the available BLAST tools (Altschul et al. 1990). A phylogenetic tree was produced with MEGA version 3.1 using default settings (Kumar et al. 2004). The 16S rRNA gene sequence was deposited with GenBank and has the accession number GU441767.1.

Bacterial cultures and media

M. aurum strain B8.A was maintained on a medium containing $20 \mathrm{mM} \mathrm{KH} \mathrm{PO}_{4}, 20 \mathrm{mM} \mathrm{K} \mathrm{HPO}_{4}, 0.75 \mathrm{mM}$
$\mathrm{MgSO}_{4} 7 \mathrm{H}_{2} \mathrm{O}, 7 \mathrm{mM} \mathrm{KCl}, 0.05 \mathrm{mM} \mathrm{FeCl}_{3} 6 \mathrm{H}_{2} \mathrm{O}, 0.2 \%(w /$ v) trypton, $1 \%(w / v)$ potato starch granules with $1 \%(v / v)$ trace elements and $1 \%(v / v)$ vitamins (MMTV) (Wijbenga et al. 1991). The composition of the trace element solution was: $3.5 \mathrm{mM} \mathrm{MnCl} 2,0.5 \mathrm{mM} \mathrm{Na}_{2} \mathrm{~B}_{4} \mathrm{O}_{7} 10 \mathrm{H}_{2} \mathrm{O}, 70 \mu \mathrm{M}$ $\mathrm{ZnSO}_{4} 7 \mathrm{H}_{2} \mathrm{O}, 30 \mu \mathrm{M} \mathrm{CuCl}_{2} 2 \mathrm{H}_{2} \mathrm{O}, 0.3 \mathrm{mM} \mathrm{H}_{3} \mathrm{BO}_{3}$, $12 \mu \mathrm{M} \mathrm{Na}{ }_{2} \mathrm{MoO}_{4} 2 \mathrm{H}_{2} \mathrm{O}, 8 \mu \mathrm{M} \mathrm{VSO}_{5} 5 \mathrm{H}_{2} \mathrm{O}, 3.5 \mu \mathrm{M}$ $\mathrm{CoSO}_{4} 7 \mathrm{H}_{2} \mathrm{O}, 25 \mathrm{mM} \mathrm{H}_{2} \mathrm{SO}_{4}$. The vitamin solution consisted of $40 \mu \mathrm{M}$ thiamine- $\mathrm{HCl}, 20 \mu \mathrm{M}$ biotin, $10 \mu \mathrm{M}$ pyridoxine- $\mathrm{HCl}, 15 \mu \mathrm{M}$ riboflavin, $35 \mu \mathrm{M} p$-aminobenzoic acid, $40 \mu \mathrm{M}$ nicotinic acid, $10 \mu \mathrm{M}$ D-Ca-pantothenate, $1 \mu \mathrm{M}$ folic acid, and $0.05 \mu \mathrm{M}$ cyanocobalamin, sterilized by ultrafiltration. The M. aurum type strain (DSMZ 8600) was obtained from the DSMZ collection (Germany). Precultures were grown in shake flasks containing Nutrient Broth (NB) medium (Wijbenga et al. 1991) for $24 \mathrm{~h}$ at $30^{\circ} \mathrm{C}$ on a rotary shaker at $200 \mathrm{rpm}$. Main cultures were grown in shake flasks containing MMTV medium for $48 \mathrm{~h}$ at $30{ }^{\circ} \mathrm{C}$ and $200 \mathrm{rpm}$. Routinely a $1 \%(v / v)$ inoculum was used. Cultivation was also performed in rich media containing either 3\%(w/v) Trypticase Soy Broth and $0.3 \%$ Yeast Extract (TSYE), or 3\% potato starch granules and $0.3 \%$ Yeast Extract (PYE) or only $0.3 \%$ Yeast Extract (YE). Starch granules were sterilized by gamma irradiation.

Screening for starch degradation was performed by inoculating bacteria on MMTV agar with $1 \%(w / v)$ granular potato starch. After incubation for $48 \mathrm{~h}$ at $30{ }^{\circ} \mathrm{C}$, a solution of $1 \% \mathrm{KI} / 0.25 \% \mathrm{I}_{2}(w / v)$ was added, visualizing starchdegrading colonies by a clear halo.

\section{Production and harvest of extracellular enzymes}

Following 3 days of batch cultivation of Microbacterium strains, the fermentation broths were collected and centrifuged at $10,000 \times g$ for $10 \mathrm{~min}$ at $4{ }^{\circ} \mathrm{C}$. The resulting cellfree supernatants containing extracellular enzymes were collected for further investigation. Protein concentrations were estimated by the Bradford method (Bio-Rad Protein Kit, Bio-Rad Lab. GmbH, Germany) (Bradford 1976). Cellfree supernatants were diluted to a protein concentration of $10 \mu \mathrm{g} \mathrm{ml}^{-1}$ with $50 \mathrm{mM}$ Tris Buffer $\mathrm{pH} 6.8$ before use in activity assay experiments.

\section{Purification of starch-binding proteins}

Granular starch-degrading enzymes were partially purified from cell free supernatants by binding to starch granules. Thus, 5\% (w/v) potato starch granules were added to supernatants prepared as described above, and the suspensions were stirred gently at $4{ }^{\circ} \mathrm{C}$. After $2 \mathrm{~h}$, the suspensions were centrifuged at $5,000 \times \mathrm{g}$ for $20 \mathrm{~min}$, and the precipitated granular starch was washed with ice-cold $50 \mathrm{mM} \mathrm{Na-}$ 
phosphate buffer ( $\mathrm{pH}$ 6.8). Adsorbed enzymes were eluted from starch granules by stirring gently in $50 \mathrm{mM}$ Naphosphate $\left(\mathrm{pH}\right.$ 6.8) at $45{ }^{\circ} \mathrm{C}$ for $1 \mathrm{~h}$ followed by centrifugation at $5,000 \times g$ for $20 \mathrm{~min}$. Supernatant containing partially purified starch-binding enzymes was collected for further analysis.

\section{Sugar analysis}

Cell-free supernatants obtained from cultures grown on MMTV containing $10 \mu \mathrm{g} \mathrm{ml}^{-1}$ protein, $100 \mu \mathrm{g} \mathrm{ml}^{-1}$ of ampicillin and $100 \mu \mathrm{g} \mathrm{ml}^{-1}$ of kanamycin, were incubated with $1 \%(w / v)$ starch granules at $37{ }^{\circ} \mathrm{C}$ with agitation at $200 \mathrm{rpm}$. Samples were removed after various time intervals. Reaction products were separated from granules by centrifugation at $5,000 \times \mathrm{g}$ for $20 \mathrm{~min}$. Reaction products were analyzed by Thin Layer Chromatography (TLC) (Silica gel $60 \mathrm{~F}_{254}$, Merck, Germany) by spotting $5 \mu \mathrm{l}$ from each time point. Products were separated with a solvent system of 1-butanol/ethanol/water $(5: 5: 3, v / v / v)$ overnight. After running, the plates were dried and sprayed with $50 \%(v / v)$ sulphuric acid in methanol and left to develop at $110^{\circ} \mathrm{C}$ (van der Kaaij et al. 2007). The reaction products from soluble substrates were also investigated by incubation of $1 \%(w / v)$ substrate for $4 \mathrm{~h}$ with cell-free supernatants of the M. aurum strains B8.A and DSMZ 8600 , diluted to a protein concentration of $10 \mu \mathrm{g} \mathrm{ml}^{-1}$, obtained from cultures grown on various rich media. Formation of products was determined qualitatively by TLC as described above.

To estimate granular starch-degrading activity, cell-free supernatants were incubated with granular starch, and the total carbohydrate released was measured with the Anthron method. Briefly, $5 \mathrm{ml} \mathrm{10 \% (w/v)} \mathrm{granular} \mathrm{starch} \mathrm{suspension}$ was mixed with $5 \mathrm{ml}$ cell-free supernatant obtained from $M$. aurum strains grown on MMTV, with a final concentration of $10 \mu \mathrm{g} \mathrm{ml}^{-1}$ protein and containing $100 \mu \mathrm{g} \mathrm{m}{ }^{-1}$ of ampicillin and $100 \mu \mathrm{g} \mathrm{ml}^{-1}$ of kanamycin. Incubations were performed in duplicate at $37{ }^{\circ} \mathrm{C}$ with agitation at $200 \mathrm{rpm}$. Samples were taken in duplicate after several time intervals up to 7 days $(148 \mathrm{~h})$; the reaction was stopped by centrifugation. Subsequently, $0.5 \mathrm{ml}$ supernatant was added to $5 \mathrm{ml}$ Anthron solution $[0.2 \%(w / v)$ Anthron powder in $200 \mathrm{ml}$ of concentrated $\mathrm{H}_{2} \mathrm{SO}_{4}$ and $60 \mathrm{ml}$ water, $15 \mathrm{ml} \mathrm{95 \%} \mathrm{ethanol]} \mathrm{and} \mathrm{incubated} \mathrm{at} 100{ }^{\circ} \mathrm{C}$ for $10 \mathrm{~min}$. The absorbance at $620 \mathrm{~nm}$ was taken as a measure of total carbohydrate present. Maltose $(20-100 \mathrm{mM})$ was used as a standard.

\section{Scanning electron microscopy}

The incubation of supernatant samples with starch granules was performed as described above (Anthron test). After incubation, starch granules were washed twice with waterethanol $(1: 1)$ and dried by heating in an oven at $55{ }^{\circ} \mathrm{C}$ for $1 \mathrm{~d}$. The samples (dried starch powder) were mounted on SEM stubs with double-sided adhesive tape and coated with gold. Scanning electron micrographs were taken using the JSM-6301F Scanning Microscope (JEOL) in the Department of Cell Biology and Electron Microscopy, Faculty of Medical Sciences, University Medical Centre Groningen, The Netherlands. The accelerating voltage $(2.0 \mathrm{kV})$ and the magnification are shown on the micrographs.

\section{Protein electrophoresis}

Analysis of starch-hydrolyzing activity on sodium dodecyl sulphate polyacrylamide gels (SDS PAGE) was conducted according to Zeeman et al. (1998). Protein samples (final concentration $30 \mathrm{ng} \mathrm{ml}^{-1}$ ) were separated on $7.5 \%(w / v)$ SDS PAGE containing $0.5 \%(w / v)$ amylopectin at a constant voltage of $150 \mathrm{~V}$ per gel for $55 \mathrm{~min}$. After electrophoresis, gels were washed twice with distilled water and once with $50 \mathrm{mM}$ Tris buffer $(\mathrm{pH}$ 6.8) and subsequently incubated overnight in the same buffer at $37^{\circ} \mathrm{C}$. Protein bands containing starch-hydrolyzing activity were visualized by staining with a solution of $1 \% \mathrm{KI} /$ $0.25 \% \mathrm{I}_{2}(w / v)$.

\section{Results}

Selection and identification of M. aurum B8.A

Samples of several mixed liquid cultures containing granular starch-degrading activity were plated out and covered with a thin agar layer containing potato starch granules. Between 1 and $5 \%$ of all colonies that appeared produced a clear halo in the turbid top layer, indicating granular starch-degrading activity. Pure cultures were isolated from several halo-forming colonies by repeatedly transferring a single colony to a new agar plate. These isolates were divided into six groups according to their properties, e.g., colony appearance, pigmentation and type of degradation of the starch granules (pore formation or peeling of layers of the granule). One of these groups, producing identical colonies, was selected for further characterization. The selected strain, B8.A, was a gram-positive, aerobic, nonmotile, coccoid rod-shaped $(0.6 \times 0.8 \mu \mathrm{m}$ in size $)$ bacterium, which did not form spores. Growth of the strain occurred within a $\mathrm{pH}$ range of 6.0 to 9.0. The strain was deposited in the $\mathrm{BCCM} / \mathrm{LMG}$ culture collection of the University of Gent, Belgium under the deposit number LMG S-26033. 
Analysis of the 16S rDNA gene of the B8.A isolate revealed highest similarity with Microbacterium species. A phylogenetic tree based on the 16S rDNA sequences of several Microbacterium species (Fig. 1) showed that strain B8.A has the highest sequence similarity with $M$. aurum strain DSMZ 8600 (GenBank accession no. GU441767.1) (99\%), Microbacterium sp. KV-492 (GenBank accession no. AB234028) (99\%), Microbacterium schleiferi (GenBank accession no. Y17237) (98\%) and Microbacterium oxydans (GenBank accession no. AB365061) (97\%). As the newly isolated microorganism was most closely related to $M$. aurum DSMZ 8600, the isolated strain was named $M$. aurum B8.A. For comparison, the M. aurum DSMZ 8600 type strain was included in all experiments reported in this study.

Granular starch-degrading activity

Granular starch-degrading activity was analyzed by growing M. aurum strains B8.A and DSMZ 8600 on MMTV agar containing granular starch. M. aurum B8.A colonies showed clear zones (halos) after iodine staining (data not shown), indicating that degradation of starch granules occurred. No halos appeared around colonies of M. aurum DSMZ 8600.

In subsequent experiments, cell-free supernatants were used as a source of extracellular enzymes. Cell-free supernatants of both $M$. aurum strains, grown on MMTV medium, were incubated with several types of starch granules. Scanning Electron Microscopy (SEM) (Fig. 2) was used to visualize the enzymatic degradation. Cell-free supernatant of $M$. aurum B8.A partially degraded starch granules from wheat (data not shown), tapioca and potato origin. It produced numerous small pores in potato starch granules (Fig. 2c) and fewer but much larger pores in tapioca starch granules (Fig. 2d). Supernatant of the type strain DSMZ8600 did not show visible degradation of any of the granular starches.
The ability of extracellular enzymes produced by $M$. aurum B8.A to degrade starch granules was quantified by measuring the total carbohydrate released from granular starch. After 7 days incubation, the cell-free supernatant of M. aurum B8.A had degraded wheat, tapioca and potato starch granules by $77 \%, 76 \%$ and $50 \%$ respectively, while cell free supernatant of strain DSMZ 8600 had only released $3 \%$ of the total amount of carbohydrate from potato starch granules (Fig. 3).

Product formation from starch

Cell-free supernatants of both strains B8.A and DSMZ 8600 were incubated with different types of starch followed by TLC analysis of the products formed. Enzymes in the cultures of M. aurum B8.A grown on MMTV (Fig. 4) or PYE (Fig. 5) media initially produced maltotriose followed by production of maltose after $2 \mathrm{~h}$ incubation with starch granules (Fig. 4) and soluble starch (Fig. 5). When grown on TSYE, a rich medium lacking starch, less activity was observed in strain B8.A supernatants and mostly larger maltooligosaccharides (but not maltose) were formed (Fig. 5). Cell-free supernatants of M. aurum DSMZ 8600 did not show activity towards starch granules and produced only very small amounts of maltotriose from all soluble starch substrates (Fig. 5).

Purification of granular starch-degrading enzymes

The presence of amylolytic enzymes in cell-free supernatants of M. aurum B8.A and DSMZ 8600 was analyzed by SDS PAGE containing amylopectin, involving separation and renaturation of extracellular enzymes, and allowing visualization of enzyme activity. Proteins with amylase activity appeared as a clear area in a blue background after staining gels with iodine (Fig. 6). Cell-free supernatants of M. aurum B8.A grown on MMTV showed seven major activity bands (Fig. 6, lane 1). When grown on PYE, M. aurum B8.A
Fig. 1 Bootstrapped phylogenetic tree of several Microbacterium species based on $16 \mathrm{~S}$ rDNA sequences. The sequence alignment and construction of the phylogenetic tree were performed with MEGA version 3.1 using default settings (Tamura et al. 2007). The bar indicates a $0.2 \%$ difference by nucleotide substitution or deletion. Bootstrap values are shown at the nodes

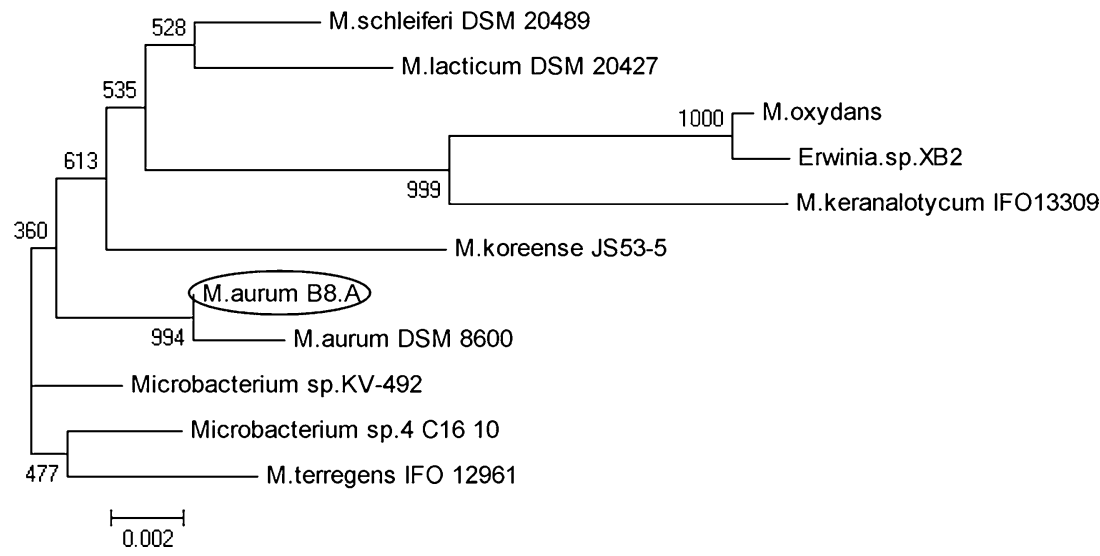


Fig. 2 Scanning electron microscopy pictures of starch granules incubated with $M$. aurum cell-free supernatants $(10 \mu \mathrm{g} / \mathrm{ml}$ protein). Starch granules were incubated with cellfree supernatants of $M$. aurum B8.A for $72 \mathrm{~h}$ (c, potato) and $24 \mathrm{~h}$ (d, tapioca) or cell free supernatants of $M$. aurum DSMZ 8600 for 7 days (e, potato; f, tapioca) compared to untreated control samples (a and b, potato and tapioca, respectively). Potato starch granules incubated for $72 \mathrm{~h}$ with PYE cell-free supernatants of $M$. aurum B8.A (g) or M. aurum DSMZ 8600 (h)
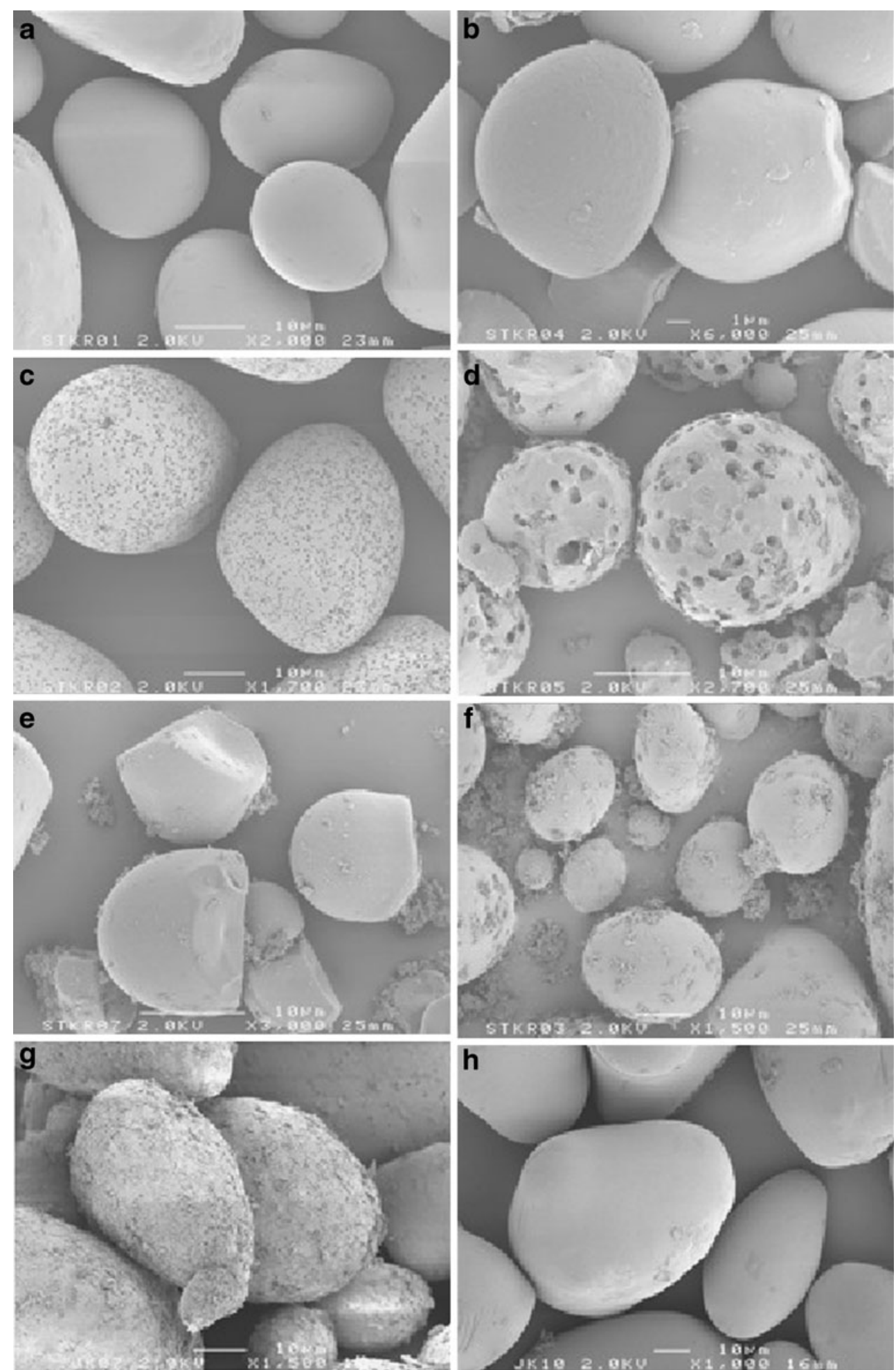

produced a clearly different set of proteins with amylase activity. M. aurum DSMZ 8600 did not produce any protein with visible amylase activity (data not shown).
Starch-binding enzymes from $M$. aurum B8.A cell-free supernatant were partially purified by binding to starch and subsequent elution at elevated temperature. After this 


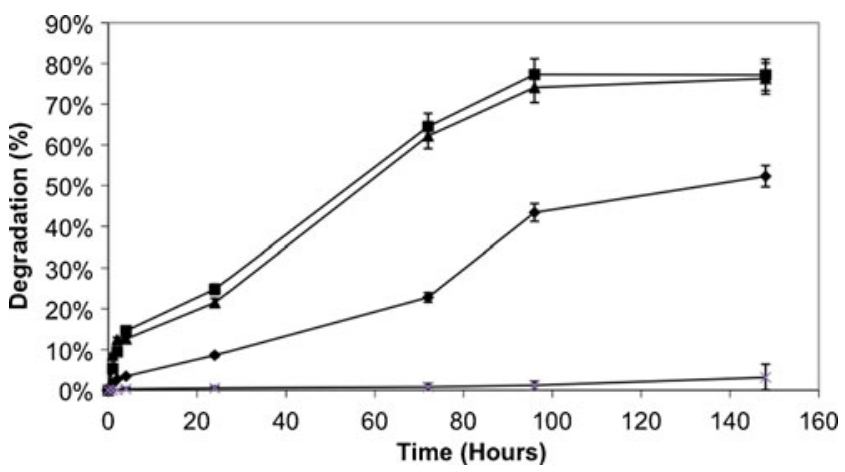

Fig. 3 Enzymatic degradation of starch granules. Degradation of starch granules $(5 \% w / v)$ by cell-free supernatants obtained from cultures of M. aurum B8.A and DSMZ 8600 grown on MMTV with $1 \%$ potato starch granules. Cell-free supernatants of M. aurum B8.A incubated with starch granules: filled squares tapioca, filled triangles wheat, filled diamonds potato, plus sign cell-free supernatants from $M$. aurum DSMZ 8600 incubated with potato starch granules

procedure, fewer bands with amylase activity were observed on SDS PAGE. The main activity band was observed from a protein with an apparent mass of approx $95 \mathrm{kD}$ (Fig. 6, lane 2).

\section{Discussion}

In this paper, we present the characteristics of the first $M$. aurum strain with the ability to degrade granular potato starch. The B8.A strain was allocated to the genus Micro-

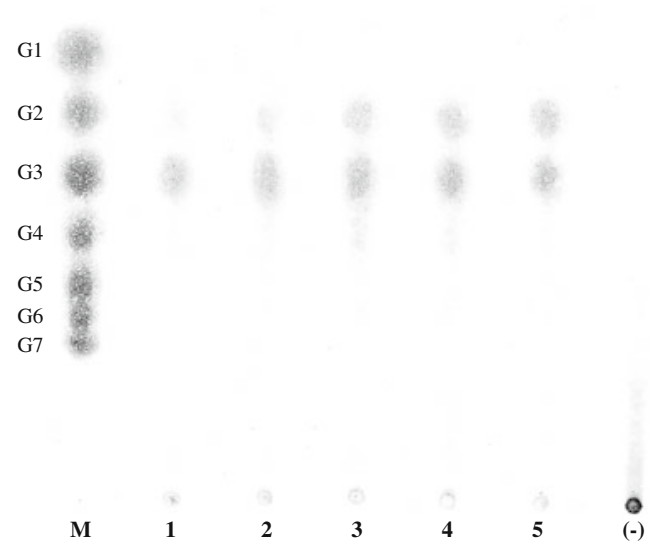

Fig. 4 TLC analysis of hydrolysis products from starch granules produced by cell free supernatants of $M$. aurum B8.A. Cell-free supernatants of $M$. aurum B8.A (10 $\mu \mathrm{g} / \mathrm{ml}$ protein) grown on MMTV media incubated with $5 \%(w / v)$ starch granules at $37{ }^{\circ} \mathrm{C}$ for various periods. $M$, Standard Glucose $(\mathrm{G} 1)$ to maltoheptaose $(G 7)$; cell-free supernatants incubated with starch granules on $37^{\circ} \mathrm{C}$ for: $11 \mathrm{~h}, 22 \mathrm{~h}$, 324 h, 448 h, 596 h; minus sign negative control (starch granules in buffer solution) bacterium in accordance with its general morphological and physiological properties and its phylogeny according to the $16 \mathrm{~S}$ rDN gene sequence. It was designated M. aurum B8.A.

To characterize and investigate its starch-degrading properties, cell-free supernatant of $M$. aurum B8.A was incubated with different types of granular starch. The partly hydrolyzed wheat and tapioca starch granules showed many holes of different sizes, depths and width on the surface of wheat and tapioca starch. On potato starch, numerous smaller-sized pores were found. No visible degradation of starch granules occurred with the cell free supernatants derived from M. aurum DSMZ 8600 even though the growth rate and extracellular protein concentration of both strains were similar. Apparently, there is a large difference in amylolytic potential between these closely related strains.

Amylase activity resulting in pore formation in maize starch granules has been reported for $B$. subtilis and barley alpha-glucosidase (Hayashida et al. 1988; Sun and Henson 1990). Other studies have reported enzyme systems which degraded the granules by peeling off layers from the surface, without apparent erosion of their internal regions (no pores detected) (Taniguchi et al. 1982).

As shown in Fig. 3, potato starch granules were degraded slowly compared to wheat and tapioca starch granules. This quantitative assessment confirmed the observation that larger holes were formed in wheat and tapioca starch granules compared to potato starch granules. It is quite apparent that starch granules from different botanical sources have widely different susceptibilities to enzymatic hydrolysis. Potato is generally less susceptible to enzymatic degradation than other starches. It has been proposed that larger granules are less easily degraded than smaller granules (Heitmann et al. 1997; Kong et al. 2003; Tester et al. 2004), partly explaining why potato starch granules being larger than most other starch granules could be less susceptible (Singh et al. 2003). In addition, potato starch and other tuber starches have a typical B-crystalline structure, and contain more water, thicker and larger growth rings (crystalline-amorphous portion) and longer average amylopectin branch chain length than other types (Buttrose 1963). It has been reported that this crystalline form is more resistant to enzymatic hydrolysis than the Atype (Gérard et al. 2001).

The extracellular amylolytic enzymes in M. aurum B8.A mainly produced maltose as their smallest product, while no glucose was formed in detectable amounts. Apparently, no or little glucosidase or glucoamylase type of activity is present, although these enzymes normally play an important role in starch degradation by microorganisms (Chen et al. 2005). Previous examinations of granular starch- 


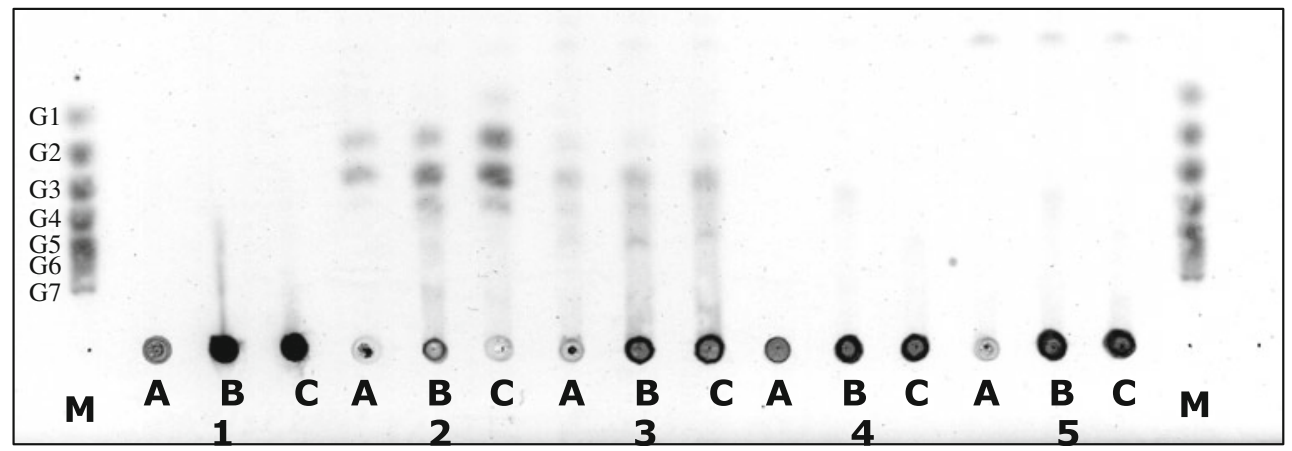

Fig. 5 TLC analysis of hydrolysis products from several substrates $(1 \% \mathrm{w} / \mathrm{v})$ produced by cell-free supernatants $(10 \mu \mathrm{g} / \mathrm{ml}$ protein) of $M$. aurum strains. $M$ standard $\mathrm{G} 1-\mathrm{G} 7, A$ amylose, $B$ amylopectin, $C$ soluble starch, 1 negative control, 2 cell-free supernatants of $M$. aurum
B8.A grown on PYE, 3 cell-free supernatants of $M$. aurum B8.A grown on TSYE, 4 cell-free supernatants of $M$. aurum DSMZ 8600 grown on PYE, 5 cell-free supernatants of $M$. aurum DSMZ 8600 grown on TSYE degrading enzymes have shown that such enzymes often contain starch-binding domains, allowing efficient binding to starch granules. This property was used to purify and select for amylolytic enzymes with the capacity to bind to granules. The partially purified enzyme preparations displayed fewer activity bands than the original cell-free supernatant (Fig. 6): mostly the larger enzymes were retained, indicating that indeed enzymes containing extra domains like SBDs to bind granules had been purified. One main activity band was purified, but it is not clear whether more than one enzyme in the culture supernatant is involved in pore formation. When searching the CaZy database (http://www.cazy.org/) for enzymes with similar specificities, like binding to raw starch and production of maltotriose, two enzymes were found, both from Gram+ organisms with a high GC content like M. aurum (Cantarel et al. 2009; Doukyu et al. 2008; Yang and Liu 2007). Both these enzymes contain an SBD of family CBM20, suggesting that the $M$. aurum raw starch-degrading amylase may have a similar structure. On the other hand, the lack of similar enzymes with other types of CBMs in the databases

Fig. 6 Activity staining for $M$. aurum B8.A amylolytic enzymes on SDSpolyacrylamide gel electrophoresis containing amylopectin. $M$ marker, $A$ MMTV cell-free supernatants of $M$. aurum B8.A, $B$ supernatants after starchbinding purification. The gel was incubated overnight at $37{ }^{\circ} \mathrm{C}$ in $50 \mathrm{mM}$ Tris, pH 6.8 and stained with an iodine solution

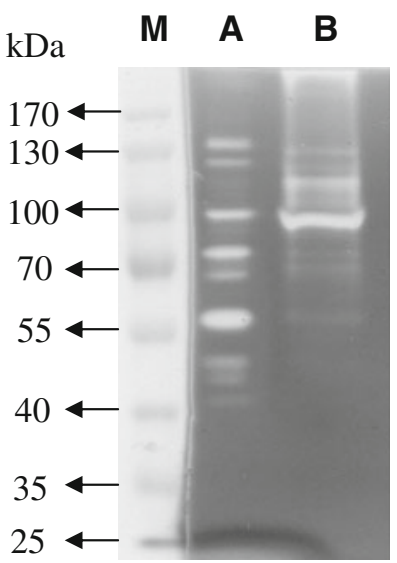

might also be representative of the fact that only a small percentage of predicted enzymes have been characterized biochemically, biasing such predictions.

According to their 16S rDNA sequences both organisms characterized in this paper are M. aurum strains; however a clear difference was observed in their ability to degrade starch granules. In all experiments performed in this study, either involving agar-grown colonies (data not shown) or cell-free supernatants of liquid grown cultures on various media, M. aurum DSMZ 8600 showed little or no amylolytic activity. Granular starch-degrading activity was only found in the $M$. aurum B8.A strain. The apparent incompleteness of the amylolytic system of $M$. aurum, with the absence of a glucoamylase or glucosidase activity, may suggest that its starch-degrading ability originates from a single enzyme, which may have been acquired by horizontal gene transfer (DaLage et al. 2004; Garcia-Vallve et al. 2000; Lawrence 1999; Poelarends et al. 2000). Although horizontal gene transfer could theoretically explain this striking difference between very closely related strains, it is not very likely in this case as no other strains with similar granule degrading ability were isolated from the waste water source. The only other strain isolated for its ability to degrade granules from the same screening, identified as a Bacillus firmus/lentus strain, did this by "peeling off" layers of the surface of the granules, which is likely to require a different set of enzymes (Wijbenga et al. 1991). This suggests that genes encoding amylolytic, pore forming, enzymes were not widely present in the microbial gene pool, not even in the environment where granular starch is an abundantly available substrate. An alternative explanation is that the type strain, M. aurum DSMZ 8600, has lost its starch-degrading ability during evolution. We are currently isolating the amylase genes of the M. aurum B8. A strain to allow a further study of its complex of amylolytic enzymes that plays a role in granular (potato) starch degradation. 
Acknowledgement F.D. Sarian was financially supported by a Bernoulli PhD student bursary from the University of Groningen. The authors thank the Netherlands Organization for Applied Scientific Research (TNO) for providing M. aurum B8.A. We also thank Itje Stokroos and Jeroen Kuipers (Cell Biology and Electron Microscopy Department, University Medical Centre Groningen, the Netherlands) for taking the SEM pictures.

Open Access This article is distributed under the terms of the Creative Commons Attribution Noncommercial License which permits any noncommercial use, distribution, and reproduction in any medium, provided the original author(s) and source are credited.

\section{References}

Al-Rabadi GJS, Gilbert RG, Gidley MJ (2009) Effect of particle size on kinetics of starch digestion in milled barley and sorghum grains by porcine alpha-amylase. J C Sci 50:198-204

Altschul SF, Gish W, Miller W, Myers EW, Lipman DJ (1990) Basic local alignment search tool. J Mol Biol 215:403-410

Bertoldo C, Antranikian G (2002) Starch-hydrolyzing enzymes from thermophilic archaea and bacteria. Curr Opin Chem Biol 6:151-160

Bradford MM (1976) A rapid and sensitive method for the quantitation of microgram quantities of protein utilizing the principle of protein-dye binding. Anal Biochem 72:248-254

Buttrose MS (1963) Electron-microscopy of acid-degraded starch granules. Starch-Starke 15:85-92

Cantarel BL, Coutinho PM, Rancurel C, Bernard T, Lombard V, Henrissat B (2009) The Carbohydrate-Active EnZymes database (CAZy): an expert resource for glycogenomics. Nucleic Acids Res 37:233-238

Chen J, Li D-C, Zhang Y-Q, Zhou Q-X (2005) Purification and characterization of a thermostable glucoamylase from Chaetomium thermophilum. J Gen Appl Microbiol 51:175-181

Christiansen C, Hachem MA, Janeček S, Viksø-Nielsen A, Blennow A, Svensson B (2009) The carbohydrate-binding module family 20 - diversity, structure, and function. FEBS J 276:5006-5029

DaLage JL, Feller G, Janecek S (2004) Horizontal gene transfer from Eukarya to bacteria and domain shuffling: the alpha-amylase model. Cell Mol Life Sci 61:97-109

de Miguel Bouzas T, Barros-Velázquez J, Villa TG (2006) Industrial application of hyperthermophilic enzymes: a review. Protein Pept Lett 13:645-651

Doukyu N, Yamagishi W, Kuwahara H, Ogino H (2008) A maltooligosaccharide-forming amylase gene from Brachybacterium sp. strain LB25: cloning and expression in Escherichia coli. Biosci Biotechnol Biochem 72:2444-2447

Fairbairn DA, Priest FG, Stark JR (1986) Extracellular amylase synthesis by Streptomyces limosus. Enzyme Microb Tech 8:89-92

Finnie C, Svensson B (2009) Barley seed proteomics from spots to structures. J Proteomics 72:315-324

Fogarty WM, Kelly CT (1990) Recent advances in microbial amylases. In: Microbial enzymes and biotechnology. Elsevier, London, pp 71-132

Garcia-Vallve S, Romeu A, Palau J (2000) Horizontal gene transfer of glycosyl hydrolases of the rumen fungi. Mol Biol Evol 17:352361

Gérard C, Colonna P, Buléon A, Planchot V (2001) Amylolysis of maize mutant starches. J Sci Food Agric 81:1281-1287

Guillén D, Sánchez S, Rodríguez-Sanoja R (2009) Carbohydratebinding domains: multiplicity of biological roles. Appl Micro Biotechn 85:1241-1249

Guzmán-Maldonado H, Parades-Lópes O (1995) Amylolytic enzymes and products derived from starch: a review. Crit Rev Food Sci Nutr 35:373-403
Hayashida S, Teramoto Y, Inoue T (1988) Production and characteristics of raw-potato-starch-digesting alpha-amylase from Bacillus subtilis 65. Appl Environ Microbiol 54:1516-1522

Heitmann T, Wenzig E, Mersmann A (1997) Characterization of three different potato starches and kinetics of their enzymatic hydrolysis by an alpha-amylase. Enzyme Microb Tech 20:259267

Holt JG, Krieg NR, Sneath PHA, Staley JT, Williams ST (1994) Bergey's manual of determinative bacteriology, 9th edn. Williams and Wilkins, Baltimore, pp 667-676

Kong B-W, Kim J-I, Kim M-J, Kim JC (2003) Porcine pancreatic alpha-amylase hydrolysis of native starch granules as a function of granule surface area. Biotech Prog 19:1162-1166

Kumar S, Tamura K, Nei M (2004) MEGA 3: integrated software for Molecular Evolutionary Genetics Analysis and sequence alignment. Brief Bioinform 5:150-163

Lawrence JG (1999) Gene transfer, speciation, and the evolution of bacterial genomes. Curr Opin Microbiol 2:519-523

MacGregor AW, Balance DL (1980) Hydrolysis of large and small starch granules from normal and waxy barley cultivars by alphaamylases from barley malt. Cereal Chem 57:397-402

Machovic M, Janecek S (2006) Starch-binding domains in the postgenome era. Cell Mol Life Sci 63:2710-2724

Maniatis M, Fritsch EF, Sambrook J (1982) Molecular cloning: a laboratory manual. Cold Spring Harbor, New York

Miah MNN, Ueda S (1977) Multiplicity of glucoamylase of Aspergillus oryzae. Starch-Starke 29:235-239

Noda T, Takigawa S, Matsuura-Endo C, Kim S-J, Hashimoto N, Yamauchi H, Hanashiro I, Takeda Y (2005) Physicochemical properties and amylopectin structures of large, small, and extremely small potato starch granules. C Polym 60:245-251

Poelarends GJ, Kulakov LA, Larkin MJ, van Hylckama Vlieg JET, Janssen DB (2000) Roles of horizontal gene transfer and gene integration in evolution of 1,3-dichloropropene- and 1,2-dibromoethane-degradative pathways. J Bacteriol 182:2191-2199

Primarini D, Ohta Y (2000) Some enzyme properties of raw starch digesting amylases from Streptomyces sp. No. 4. Starch-Starke 52:28-32

Robertson GH, Wong DWS, Lee CC, Wagschal K, Smith MR, Orts WJ (2005) Native or raw starch digestion: a key step in energy efficient biorefining of grain. J Agric Food Chem 54:353-365

Rodriguez-Sanoja R, Ruiz B, Guyot JP, Sanchez S (2005) Starchbinding domain affects catalysis in two Lactobacillus alphaamylases. Appl Environ Microbiol 71:297-302

Sarikaya E, Higasa T, Adachi M, Mikami B (2000) Comparison of degradation abilities of alpha- and beta-amylases on raw starch granules. Process Biochem 35:711-715

Singh N, Singh J, Kaur L, Singh Sodhi N, Singh Gill B (2003) Morphological, thermal and rheological properties of starches from different botanical sources. Food Chem 81:219-231

Southall SM, Simpson PJ, Gilbert HJ, Williamson G, Williamson MP (1999) The starch-binding domain from glucoamylase disrupts the structure of starch. FEBS Lett 447:58-60

Sun Z, Henson CA (1990) Degradation of native starch granules by barley alpha-glucosidases. Plant Physiol 94:320-327

Tamura K, Dudley J, Nei M, Kumar S (2007) MEGA4: Molecular Evolutionary Genetics Analysis (MEGA) software version 4.0. Mol Biol Evol 24:1596-1599

Taniguchi H, Odasima F, Makoto I, Maruyama Y, Nakamura M (1982) Characterization of a potato starch-digesting bacterium and its production of amylase. Agric Biol Chem 46(8):21072115

Tester RF, Karkalas J, Qi X (2004) Starch structure and digestibility enzyme-substrate relationship. World Poultry Sci J 60:186-195

Ueda S, Ohba R, Kano S (1974) Fractionation of the glucoamylase system from black-koji mold and the effects of adding isoamy- 
lase and alpha-amylase on amylolysis by the glucoamylase fractions. Starch-Starke 26:374-378

Uitdehaag JC, Mosi R, Kalk KH, van der Veen BA, Dijkhuizen L, Withers SG, Dijkstra BW (1999) X-ray structures along the reaction pathway of cyclodextrin glycosyltransferaseelucidate catalysis in the alpha-amylase family. Nat Struct Biol 6:432-436 van der Kaaij RM, Yuan XL, Franken A, Ram AFJ, Punt PJ, van der Maarel MJEC, Dijkhuizen L (2007) Two novel, putatively cell wall-associated and glycosylphosphatidylinositol-anchored alpha-glucanotransferase enzymes of Aspergillus niger. Eukaryot Cell 6:1178-1188

van der Maarel MJEC, van der Veen B, Uitdehaag JCM, Leemhuis H, Dijkhuizen L (2002) Properties and applications of starch- converting enzymes of the alpha-amylase family. J Biotech 94:137-155

Whitcomb DC, Lowe ME (2007) Human pancreatic digestive enzymes. Dig Dis Sci 52:1-17

Wijbenga D-J, Beldman G, Veen A, Binnema DJ (1991) Production of native-starch-degrading enzymes by a Bacillus firmus/lentus strain. Appl Microbiol Biotech 35:180-184

Yang CH, Liu WH (2007) Cloning and characterization of a maltotriose-producing $\alpha$-amylase gene from Thermobifida fusca. $\mathrm{J}$ Industr Microb Biotech 34:325-330

Zeeman SC, Northrop F, Smith AM, Rees TA (1998) A starchaccumulating mutant of Arabidopsis thaliana deficient in a chloroplastic starch-hydrolysing enzyme. Plant J 15:357-365 